\title{
Cav2.3 R-type calcium channels: from its discovery to pathogenic de novo CACNA1E variants: a historical perspective
}

\author{
T. Schneider $^{1}$ (I) $\cdot$ F. Neumaier ${ }^{1} \cdot$ J. Hescheler ${ }^{1} \cdot$ S. Alpdogan ${ }^{1}$ \\ Received: 9 March 2020 / Revised: 5 May 2020 / Accepted: 6 May 2020 / Published online: 11 June 2020 \\ (C) The Author(s) 2020
}

\begin{abstract}
So-called pharmacoresistant (R-type) voltage-gated $\mathrm{Ca}^{2+}$ channels are structurally only partially characterized. Most of them are encoded by the CACNA1E gene and are expressed as different $\mathrm{Ca}_{\mathrm{v}} 2.3$ splice variants (variant $\mathrm{Ca}_{\mathrm{v}} 2.3 \mathrm{a}$ to $\mathrm{Ca}_{\mathrm{v}} 2.3 \mathrm{e}$ or $\mathrm{f}$ ) as the ion conducting subunit. So far, no inherited disease is known for the CACNA1E gene but recently spontaneous mutations leading to early death were identified, which will be brought into focus. In addition, a short historical overview may highlight the development to understand that upregulation during aging, easier activation by spontaneous mutations or lack of bioavailable inorganic cations $\left(\mathrm{Zn}^{2+}\right.$ and $\left.\mathrm{Cu}^{2+}\right)$ may lead to similar pathologies caused by cellular overexcitation.
\end{abstract}

Keywords CACNA1E $\cdot$ Developmental and epileptic encephalopathy $\cdot$ Activation gate $\cdot$ Voltage sensor $\cdot$ Splice variants

\section{Introduction}

In the human gene of the pharmacoresistant $\mathrm{Ca}_{\mathrm{v}} 2.3 / \mathrm{R}$-type calcium channel, de novo pathogenic mutations were detected in a group of 30 individuals with developmental and epileptic encephalopathies [13]. The publication represents the first comprehensive investigation in humans with structural variations in this widely expressed voltage-gated calcium channel, together with two earlier reports, in which single cases were mentioned $[4,6]$.

Based on a short historical overview for the performed basic research, the path and the reasons for an improved understanding of the reported human mutations will be described. Interestingly, most of the channel mutations cluster within the cytoplasmic ends of the four S6 transmembrane segments (Fig. 1), which constitute part of the $\mathrm{Ca}_{\mathrm{v}} 2.3$-channel activation gate.

This article is part of the special issue on Channelopathies: from mutation to diseases in Pflügers Archiv-European Journal of Physiology

T. Schneider

toni.schneider@uni-koeln.de

1 Universitat zu Koln, 50931 Köln, Germany

\section{"Activation gate" as a functional domain in voltage-gated ion channels}

Ion channels represent transmembrane proteins, which are linked by their special structure and gating properties to many physiological functions, including cardiac and neuronal excitability. Ion channels can be either open or closed, and they contain structural elements, which are connected to the transition between these two states. The word "gate" is used to describe this concept, and "gating" is the process whereby the gate is opened and closed [1].

Ligand-gated and voltage-gated channels are activated by different processes but may both include the movement of some internal parts of the molecule to produce an effect in a different part of it to open the permanent pathway permitting the movement of ions. The cytoplasmic parts from the $\mathrm{Ca}_{\mathrm{v}} 2.3 \mathrm{~S} 6$ segments (Fig. 1) represent at least the major "internal part" of the molecule, which causes activation of the channel to open it properly and precisely.

Much more is known by crystallography and mutational analyses about the structural details, which help to convert electrical signals generated by small ion currents across cell membranes to tune all rapid processes in biology and especially in voltagegated $\mathrm{Ca}^{2+}$ and $\mathrm{Na}^{+}$channels [8]. These channels contain a tetramer of membrane-bound domains including a positively charged S4 segment. Voltage-dependent activation drives the outward movements of these positive gating changes in the voltage sensor via a "sliding-helix mechanism", which leads to a conformational change in the pore module that opens its 
intracellular activation gate (for further details related to the "chemical basis for electrical signalling", see [8]).

Another recent review specializes on the Cav1.2/L-type $\mathrm{Ca}^{2+}$ channel, which is important for the plateau of the cardiac action potentials, muscle contractions, generation of pacemaker potentials, release of hormones and neurotransmitters, sensory functions and regulated gene expression [14]. Based on gating studies using biophysical and pharmacological studies as well as mathematical simulations, the role of voltage sensors in channel opening was analysed. The gating process is determined by distinct sub-processes, the movements of the voltage-sensing domains (the charged S4 segments) and the opening and closure of S6 gates (for further details related to the individual transitions during activation, see [14]).

The first structural details for the potential coupling between voltage sensors and the pore region came from the crystals of $\mathrm{K}^{+}$ channels [10]. The question arose: how the movement of the S4 segment is transmitted to the S6 helix to open the gate upon depolarization? In the electromechanical coupling model designed for the $\mathrm{K}_{\mathrm{v}} 1.2$ channel [20], the S4-S5 linker was located within atomic proximity (4-5 A) of the $\mathrm{S} 6$ helix. Thus, it may interact with the latter in the closed state of the channel and was confirmed by double mutant cycle analysis for the expressed human $\mathrm{Ca}_{\mathrm{v}} 2.3$ channel (for further details, see [40]).

\section{History - detection of R-type and "E-type" voltage-gated calcium channels (Tab. 1)}

R-type (or initially called "E-type" [33]) $\mathrm{Ca}^{2+}$ channels were identified as the second last member of the group of high-voltage activated (HVA) $\mathrm{Ca}^{2+}$ channels [29]. They are divided into two subfamilies, (i) the L-type channels containing $\mathrm{Ca}_{\mathrm{v}} 1.1-, \mathrm{Ca}_{\mathrm{v}} 1.2-, \mathrm{Ca}_{\mathrm{v}} 1.3-$ and $\mathrm{Ca}_{\mathrm{v}} 1.4-\alpha 1$ subunits as the ion-conducting pore and (ii) the non-L-type channels containing $\mathrm{Ca}_{\mathrm{v}} 2.1$ (P-/Q-type)-, $\mathrm{Ca}_{\mathrm{v}} 2.2\left(\mathrm{~N}\right.$-type)- and $\mathrm{Ca}_{\mathrm{v}} 2.3$ (R-type)- $\alpha 1$ subunits as the proteins containing the ion-conducting pore. Lowvoltage activated (LVA) $\mathrm{Ca}^{2+}$ channels were structurally defined later by in silico cloning $[28,30]$ and contain the $\alpha 1$ subunits of T-type channels $\left(\mathrm{Ca}_{\mathrm{v}} 3.1-, \mathrm{Ca}_{\mathrm{v}} 3.2-\right.$ and $\mathrm{Ca}_{\mathrm{v}} 3.3-1$ ) [42] with less homology to two former subfamilies $\mathrm{Ca}_{\mathrm{v}} 1$ and $\mathrm{Ca}_{\mathrm{v}} 2$. The ion-conducting subunit may be in most cases associated with a set of auxiliary subunits [9] and additional interaction partners as proteins binding to cytosolic loops or competing with auxiliary subunits $[16,17]$. Within the native environment, they may typically function in the context of macromolecular signalling complexes including various upstream modulators and downstream effectors, which may be kept together by additional adapter and scaffold proteins [7].

In 1992, this novel R-type $\mathrm{Ca}^{2+}$ channel was initially detected from a rabbit brain, which was named the BII calcium channel [25]. Its primary sequence was deduced by molecular homology cloning and sequencing of cDNA. Its transcripts were found to be distributed predominantly in the cerebral cortex, hippocampus and corpus striatum. In the carboxyterminal region, 2 splice variants were found, from which BII-2 had a 272-aas-long insertion in the carboxyterminus (Fig. 2).

In 1993, a structural homolog of the new calcium channel was cloned from marine ray [12, 15, 43] and rat brain [37], which at that time was functionally expressed for the first time. Although

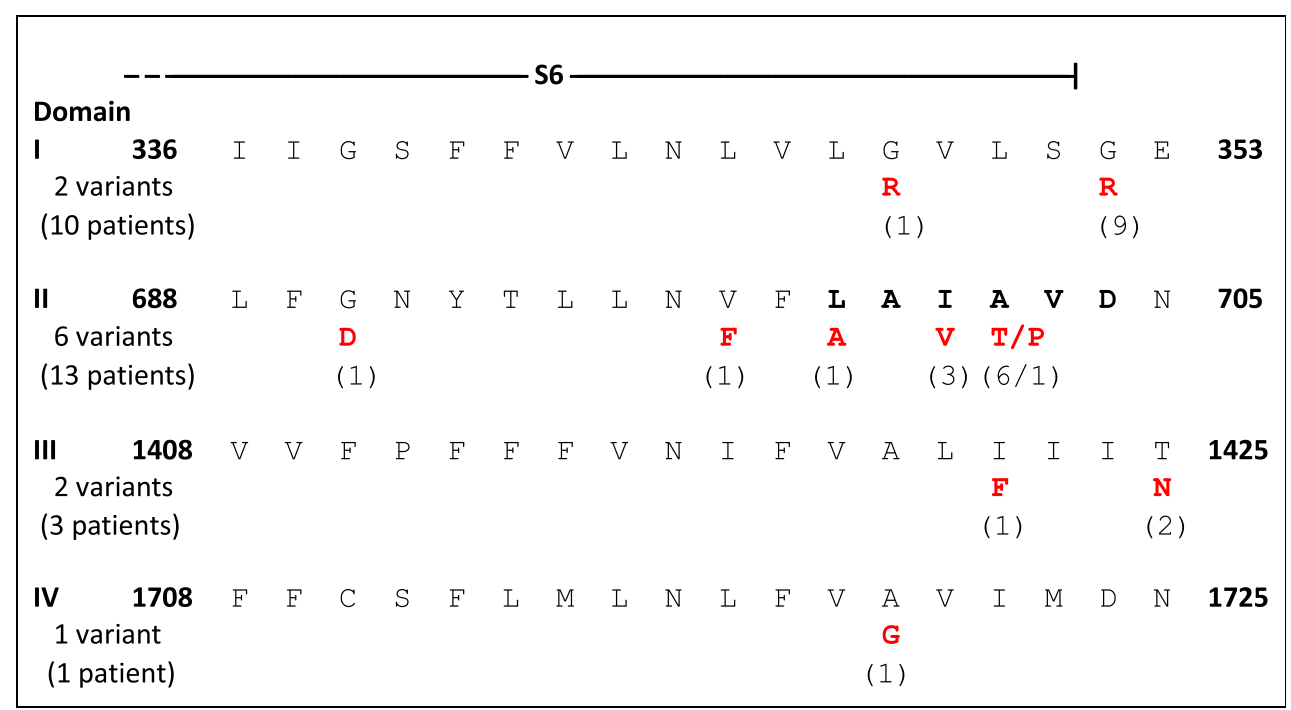

Fig. 1 Alignment of the cytoplasmic parts from the $\mathrm{Ca}_{\mathrm{v}} 2.3 \mathrm{~S} 6$ segments including 11 out of 14 identified disease-causing missense mutations, GenBank L27745.2 (inspired by Fig. 1 and Fig. S3 in Helbig et al., 2018). Note that for the mutants identified in domain II, recombinant studies have shown that the distal part of $\mathrm{Ca}_{\mathrm{v}} 2.3$ is important for the stability of the open state of $\mathrm{Ca}_{\mathrm{v}} 2.3$ [32]. Further, the first evidence for a strong electromechanical coupling between S4-S5 and the S6 of domain II came from a double mutant cycle analysis of the human $\mathrm{Ca}_{\mathrm{v}} 2.3$ confirming the hypothesis that leucine-596 in the IIS4-S5 linker couples strongly to the distal residues in IIS6 (L A I A V D) labelled in bold in this figure [40]. Three out of 30 mutations were located in IS5 (L228P), IIS4-5 (I603L) and IIIS6-IVS1 (G1430N) 
Table 1 Time table for the structural and functional identification of $\mathrm{Ca}_{\mathrm{v}} 2.3$ variants in rabbit, ray, rat, mouse and human. A generalized and systematic overview for the $\mathrm{Ca}_{\mathrm{v}} 2.3$ splice variant nomenclature was published [27]

\begin{tabular}{|c|c|c|c|c|c|}
\hline Year & Species & $\begin{array}{l}\text { GenBank accession } \\
\text { number }\end{array}$ & $\begin{array}{l}\text { Nomenclatures (in bold } \\
\text { are the present systematic } \\
\text { names) }\end{array}$ & Miscellaneous & References \\
\hline 1992 & $\begin{array}{l}\text { Rabbit (Oryctolagus } \\
\text { cuniculus) }\end{array}$ & X67855, X67856 & BII-1, BII-2 & $\begin{array}{l}\text { Deduced primary sequence, } \\
\text { no functional expression yet }\end{array}$ & {$[25]$} \\
\hline 1993 & Ray (Discopyge ommata) & L12531 & doe-1, R-type, $\mathbf{C} \mathbf{a}_{\mathbf{v}} \mathbf{2 . 3}$ & Rapid inactivating channel & {$[12,15,43]$} \\
\hline 1993 & Rat & L15453 & rbe-II, R-type & Shorter amino terminus & {$[37]$} \\
\hline 1994 & Human, foetal & L27745.2 & E-type, $\alpha 1 E d, \mathbf{C a}_{\mathbf{v}} \mathbf{2 . 3 d}$ & $\begin{array}{l}\text { Longer splice variant, including } \\
\text { exon } 19 \text { and exon } 45 \\
\text { encoded insertions }\end{array}$ & {$[26,33]$} \\
\hline 1994 & Human, adult & $\begin{array}{l}\text { L29384 } \\
\text { L29385 }\end{array}$ & $\begin{array}{l}\alpha 1 \mathrm{E}-1, \mathbf{C a}_{\mathbf{v}} \mathbf{2 . 3 a} \\
\alpha 1 \mathrm{E}-3, \mathbf{C} \mathbf{a}_{\mathbf{v}} 2.3 \mathbf{c}\end{array}$ & $\begin{array}{l}\text { Lacking exon } 19 \text { and } 45 \\
\text { Lacking exon } 45 \text { only }\end{array}$ & {$[41]$} \\
\hline 1994 & Mouse & L29346 & $\alpha 1 \mathrm{E}-3, \mathbf{C a} \mathbf{a}_{\mathbf{v}} \mathbf{2 . 3 c}$ & Lacking exon 45 only & {$[41]$} \\
\hline 1994 & Rabbit & X67856 & BII-2, class E, $\mathbf{C} \mathbf{a}_{\mathbf{v}} \mathbf{2 . 3}$ & Functional expression & {$[39]$} \\
\hline 1998 & Rat, mouse, human & (PCR fragments) & $\alpha 1 \mathrm{Ee}, \mathbf{C a} \mathbf{a}_{\mathbf{v}} \mathbf{2 . 3 e}$ & $\begin{array}{l}\text { Predicted novel splice variant } \\
\text { in cardiac and endocrine cell } \\
\text { lines }\end{array}$ & {$[38]$} \\
\hline 2002 & Rat & AY029412 & $\alpha 1 \mathrm{E} 7, \mathbf{C} \mathbf{a}_{\mathbf{v}} \mathbf{2 . 3 e}$ & $\begin{array}{l}\text { Cardiac cell line, distribution } \\
\text { in atrium and ventricle }\end{array}$ & {$[18,21,22]$} \\
\hline
\end{tabular}

a

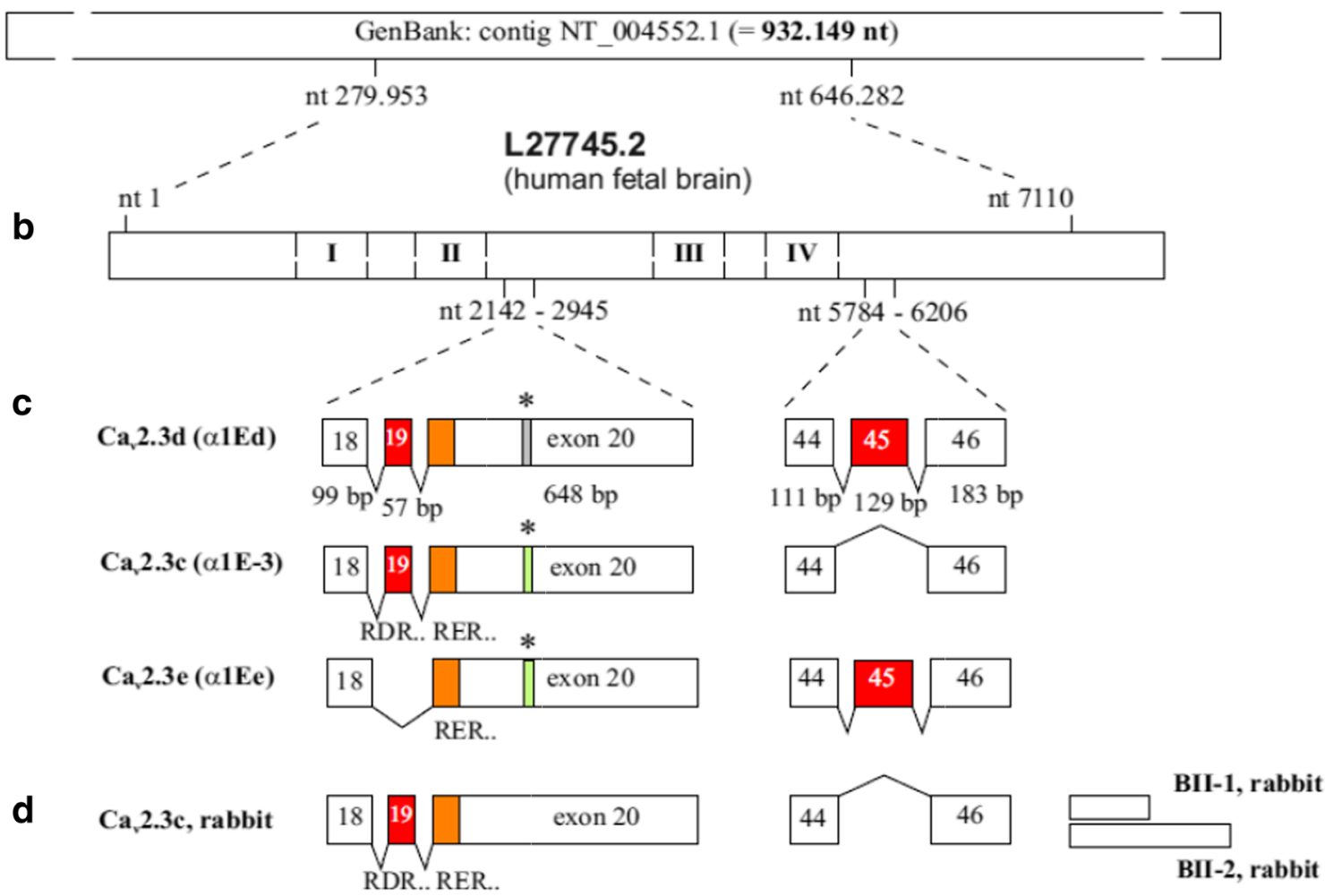

Inserts: Nr. $1 \quad$ Nr. 2 (* within exon 20) Nr. 3

\section{N-terminus \\ II-III loop \\ C-terminus}

Fig. 2 Splice variants of Cav2.3 calcium channels. In the carboxyterminal region, 2 splice variants were found, from which BII-2 had a 272 -aas-long insertion in the carboxyterminus 
the sequence of the rat rbE-II was structurally related to high voltage-activated $\mathrm{Ca}^{2+}$ channels, it was assumed to be a lowvoltage-gated $\mathrm{Ca}^{2+}$ channel, because the rbE-II channel transiently activated at more negative membrane potentials, required a strong hyperpolarization to deinactivate and was highly sensitive to $\mathrm{Ni}^{2+}$ block. In situ hybridization showed that rbE-II messenger RNA was expressed in regions throughout the central nervous system [37]. Its predicted shorter N-terminal sequence was not confirmed by RT-PCR studies [34].

During the same time, a rapidly inactivating neuronal $\mathrm{Ca}^{2+}$ channel was identified, called doe-1 in ray (Discopyge ommata). Its expression showed that it was a high-voltageactivated $\mathrm{Ca}^{2+}$ channel that inactivated more rapidly than other known channel types like L- or P-type channels. It was insensitive towards dihydropyridine antagonists or the peptide toxin omega-Aga-IVa, respectively. This channel with novel functional properties was also sensitive towards micromolar $\mathrm{Ni}^{2+}$ concentrations as well as sensitive towards omegaconotoxin GVIA in a reversible manner [12]. At that time, a similar $\mathrm{Ca}^{2+}$ channel current was identified in rat cerebellar granule neurons [43], which was distinguished from T-type $\mathrm{Ca}^{2+}$ channels in dissociated neurons from native tissues [31].

In 1994, two human Cav2.3 sequences were published [33, 41] and both constructs were functionally expressed. In the same year, also the rabbit BII-2 variant and the mouse construct (Table 1) were identified. Additional and novel splice variants were amplified by RT-PCR [38] and full-length cloning [18, 21, 22], which showed that structural and functional details are important in different tissues. The functional implications have only partially been characterized $[17,19]$.

\section{Changes of $\mathrm{Ca}_{\mathrm{v}} 2.3$ transcript and expression levels in mouse models related to Parkinson disease}

The neuronal $\mathrm{Ca}^{2+}$ sensor protein (NCS) was identified to be important for the viability and pathophysiology of dopaminergic (DA) midbrain neurons [11]. In a mouse model lacking NCS type 1 (NCS-1), several mitochondrial encoded proteins were reduced on the transcriptional level. Also, lower levels of $\mathrm{Ca}_{\mathrm{v}} 2.3$ were detected in substantia nigra (SN) neurons from NCS-1 KO mice [36], leading to a deeper analysis of the role of $\mathrm{Ca}_{\mathrm{v}} 2.3$ during the selective degeneration of DA midbrain neurons.

In an in vivo mouse model of Parkinson disease (injection of MPTP/probenecid), $\mathrm{Ca}_{\mathrm{v}} 2.3$ was identified as a mediator of SN dopaminergic neuron loss [5]. In adult SN dopaminergic neurons, it was shown that $\mathrm{Ca}_{\mathrm{v}} 2.3$ represents the most abundantly expressed voltage-gated $\mathrm{Ca}^{2+}$ channel subtype. It was linked with metabolic stress in these neurons or with their degeneration in Parkinson's disease, which may occur by affecting $\mathrm{Ca}_{\mathrm{v}}$-mediated $\mathrm{Ca}^{2+}$ oscillations and/or by changing
$\mathrm{Ca}^{2+}$-dependent after hyperpolarizations (AHPs) in SN dopaminergic neurons [5].

\section{Tonic inhibition of $\mathrm{Ca}_{\mathrm{v}} 2.3$ by bioavailable divalent cations $\left(\mathrm{Zn}^{2+}, \mathrm{Cu}^{2+}\right)$}

$\mathrm{Ca}_{\mathrm{v}}$ 2.3/R-type $\mathrm{Ca}^{2+}$ channels are highly sensitive towards bioavailable divalent cations [23]. In the organotypic model of the isolated and superfused bovine retina, $\mathrm{Ca}_{v} 2.3 / \mathrm{R}$-type $\mathrm{Ca}^{2+}$ channels have early been identified to be modulated by $\mathrm{Zn}^{2+}$ [35] and $\mathrm{Cu}^{2+}$ [24], Lüke et al., in press) changing the transretinal signalling. $\mathrm{Zn}^{2+}$ and $\mathrm{Cu}^{2+}$ effects can be analysed more specifically in heterologous expression systems, which have shown that e.g. $\mathrm{Zn}^{2+}$ can either increase or inhibit $\mathrm{Ca}^{2+}$ currents mediated by recombinant $\mathrm{Ca}_{\mathrm{v}} 2.3$ channels (Neumaier et al., unpublished results).

In vivo, $\mathrm{Ca}_{\mathrm{v}} 2.3 / \mathrm{R}$-type $\mathrm{Ca}^{2+}$ channels are thought to be under tight allosteric control by endogenous loosely bound trace metal cations $\left(\mathrm{Zn}^{2+}\right.$ and $\left.\mathrm{Cu}^{2+}\right)$ that suppress channel gating via a high-affinity trace-metal-binding site. Unexpectedly, in wild-type mice the intracerebroventricular administration of histidine $(1 \mathrm{mM})$ rather than $\mathrm{Zn}^{2+}$ itself in micromolar concentrations is beneficial during experimentally induced epilepsy [2]. In $\mathrm{Ca}_{\mathrm{v}} 2.3$-deficient mice, no beneficial effect of histidine is found and the experimentally induced seizures are less severe when $\mathrm{Zn}^{2+}$ in the presence of histidine is injected intracerebroventricularly [3].

As highly selective Cav2.3/R-type antagonists are still missing, the indirect modulation of $\mathrm{Ca}_{\mathrm{v}} 2.3$ by manipulation of bioavailable cation levels may provide an additional pathway for beneficial modulation of $\mathrm{Ca}_{\mathrm{v}} 2.3 / \mathrm{R}$-type $\mathrm{Ca}^{2+}$ channels.

Acknowledgements Open Access funding provided by Projekt DEAL. We thank Renate Clemens for her excellent technical assistance.

Funding information This work was financially supported by the German Research Foundation (Deutsche Forschungsgemeinschaft DFG, SCHN 387/21-1 and /21-2).

\section{Compliance with ethical standards}

Conflict of interest The authors declare that they have no conflict of interest.

Open Access This article is licensed under a Creative Commons Attribution 4.0 International License, which permits use, sharing, adaptation, distribution and reproduction in any medium or format, as long as you give appropriate credit to the original author(s) and the source, provide a link to the Creative Commons licence, and indicate if changes were made. The images or other third party material in this article are included in the article's Creative Commons licence, unless indicated otherwise in a credit line to the material. If material is not included in the article's Creative Commons licence and your intended use is not permitted by statutory regulation or exceeds the permitted use, you will need to obtain permission directly from the copyright holder. To view a copy of this licence, visit http://creativecommons.org/licenses/by/4.0/. 


\section{References}

1. Aidley DJ, Stanfield PR (1996) Ion channels. Molecules in action. Cambridge University Press, Cambridge

2. Alpdogan S, Neumaier F, Dibue-Adjei M, Hescheler J, Schneider T (2019) Intracerebroventricular administration of histidine reduces kainic acid-induced convulsive seizures in mice. Exp Brain Res 237:2481-2493. https://doi.org/10.1007/s00221-019-05605-Z

3. Alpdogan S, Neumaier F, Hescheler J, Albanna W, Schneider T (2020) Experimentally induced convulsive seizures are modulated in part by zinc ions through the pharmacoresistant Cav2.3 calcium channel. Cell Physiol Biochem 54:180-194. https://doi.org/10. 33594/000000213

4. Baker JJ, Burton JE, Akbar AX, Zelaya BM, Hoganson GE (2016) Case report: mutation in CACNA1E causing encephalopathy and seizure disorder; a new disorder? ACMG Ann Clin Gen Meeting March 8th - 12th: http://epostersonline.com/acmg2016/node/2302

5. Benkert J, Hess S, Roy S, Beccano-Kelly D, Wiederspohn N, Duda J, Simons C, Patil K, Gaifullina A, Mannal N, Dragicevic E, Spaich D, Muller S, Nemeth J, Hollmann H, Deuter N, Mousba Y, Kubisch C, Poetschke C, Striessnig J, Pongs O, Schneider T, Wade-Martins R, Patel S, Parlato R, Frank T, Kloppenburg P, Liss B (2019) Cav2.3 channels contribute to dopaminergic neuron loss in a model of Parkinson's disease. Nat Commun 10:5094. https://doi.org/10. 1038/s41467-019-12834-x

6. Breitenkamp AF, Matthes J, Herzig S (2015) Voltage-gated calcium channels and autism spectrum disorders. Curr Mol Pharmacol 8:123-132

7. Campiglio M, Flucher BE (2015) The role of auxiliary subunits for the functional diversity of voltage-gated calcium channels. J Cell Physiol 230:2019-2031. https://doi.org/10.1002/jcp.24998

8. Catterall WA, Wisedchaisri G, Zheng N (2017) The chemical basis for electrical signaling. Nat Chem Biol 13:455-463. https://doi.org/ $10.1038 /$ nchembio. 2353

9. Dolphin AC (2016) Voltage-gated calcium channels and their auxiliary subunits: physiology and pathophysiology and pharmacology. J Physiol 594:5369-5390. https://doi.org/10.1113/JP272262

10. Doyle DA, Cabral JM, Pfuetzner RA, Kuo AL, Gulbis JM, Cohen SL, Chait BT, MacKinnon R (1998) The structure of the potassium channel: molecular basis of $\mathrm{K}^{+}$conduction and selectivity. Science 280:69-77

11. Dragicevic E, Poetschke C, Duda J, Schlaudraff F, Lammel S, Schiemann J, Fauler M, Hetzel A, Watanabe M, Lujan R, Malenka RC, Striessnig J, Liss B (2014) Cav1.3 channels control D2-autoreceptor responses via NCS-1 in substantia nigra dopamine neurons. Brain 137:2287-2302. https://doi.org/10.1093/brain/ awu131

12. Ellinor PT, Zhang JF, Randall AD, Zhou M, Schwarz TL, Tsien RW, Horne WA (1993) Functional expression of a rapidly inactivating neuronal calcium channel. Nature 363:455-458

13. Helbig KL, Lauerer RJ, Bahr JC, Souza IA, Myers CT, Uysal B, Schwarz N, Gandini MA, Huang S, Keren B, Mignot C, Afenjar A, Billette S, Heron DV, Nava C, Valence S, Buratti J, Fagerberg CR, Soerensen KP, Kibaek M, Kamsteeg EJ, Koolen DA, Gunning B, Schelhaas HJ, Kruer MC, Fox J, Bakhtiari S, Jarrar R, PadillaLopez S, Lindstrom K, Jin SC, Zeng X, Bilguvar K, Papavasileiou A, Xin Q, Zhu C, Boysen K, Vairo F, Lanpher BC, Klee EW, Tillema JM, Payne ET, Cousin MA, Kruisselbrink TM, Wick MJ, Baker J, Haan E, Smith N, Corbett MA, MacLennan AH, Gecz J, Biskup S, Goldmann E, Rodan LH, Kichula E, Segal E, Jackson KE, Asamoah A, Dimmock D, McCarrier J, Botto LD, Filloux F, Tvrdik T, Cascino GD, Klingerman S, Neumann C, Wang R, Jacobsen JC, Nolan MA, Snell RG, Lehnert K, Sadleir LG, Anderlid BM, Kvarnung M, Guerrini R, Friez MJ, Lyons MJ, Leonhard J, Kringlen G, Casas K, El Achkar CM, Smith LA,
Rotenberg A, Poduri A, Sanchis-Juan A, Carss KJ, Rankin J, Zeman A, Raymond FL, Blyth M, Kerr B, Ruiz K, Urquhart J, Hughes I, Banka S, UBS H, Scheffer IE, Helbig I, Zamponi GW, Lerche H, Mefford HC (2018) De novo pathogenic variants in CACNA1E cause developmental and epileptic encephalopathy with contractures, macrocephaly, and dyskinesias. Am J Hum Genet 103:666-678. https://doi.org/10.1016/j.ajhg.2018.09.006

14. Hering S, Zangerl-Plessl EM, Beyl S, Hohaus A, Andranovits S, Timin EN (2018) Calcium channel gating. Pflugers Arch 470: 1291-1309. https://doi.org/10.1007/s00424-018-2163-7

15. Horne WA, Ellinor PT, Inman I, Zhou M, Tsien RW, Schwarz TL (1993) Molecular diversity of $\mathrm{Ca}^{2+}$ channel $\alpha_{1}$ subunits from the marine ray Discopyge ommata. Proc Natl Acad Sci U S A 90:37873791

16. Kaeser PS, Deng L, Wang Y, Dulubova I, Liu X, Rizo J, Sudhof TC (2011) RIM proteins tether Ca2+ channels to presynaptic active zones via a direct PDZ-domain interaction. Cell 144:282-295. https://doi.org/10.1016/j.cell.2010.12.029

17. Klöckner U, Pereverzev A, Leroy J, Krieger A, Vajna R, Hescheler J, Pfitzer G, Malecot CO, Schneider T (2004) The cytosolic II-III loop of Cav2.3 provides an essential determinant for the phorbol ester-mediated stimulation of E-type $\mathrm{Ca} 2+$ channel activity. Eur J Neurosci 19:2659-2668

18. Larsen JK, Mitchell JW, Best PM (2002) Quantitative analysis of the expression and distribution of calcium channel alpha 1 subunit mRNA in the atria and ventricles of the rat heart. J Mol Cell Cardiol 34:519-532

19. Leroy J, Pereverzev A, Vajna R, Qin N, Pfitzer G, Hescheler J, Malécot CO, Schneider T, Klöckner U (2003) $\mathrm{Ca}^{2+}$-sensitive regulation of E-type $\mathrm{Ca}^{2+}$ channel activity depends on an arginine rich region in the cytosolic II-III loop. Eur J Neurosci 18:841-855

20. Long SB, Campbell EB, MacKinnon R (2005) Voltage sensor of Kv1.2: structural basis of electromechanical coupling. Science 309: 903-908

21. Mitchell JW, Larsen JK, Best PM (1999) Sequence of E-type calcium channel gene isoforms from atrial myocytes and the cellular distribution of their protein products. Biophys J 76:A91

22. Mitchell JW, Larsen JK, Best PM (2002) Identification of the calcium channel alpha $1 \mathrm{E}(\mathrm{Ca}(\mathrm{v}) 2.3)$ isoform expressed in atrial myocytes. Biochim Biophys Acta 1577:17-26

23. Neumaier F, Dibué-Adjei M, Hescheler J, Schneider T (2015) Voltage-gated calcium channels: determinants of channel function and modulation by inorganic cations. Progress in Neurobiology 129:1-36

24. Neumaier F, Akhtar-Schafer I, Luke JN, Dibue-Adjei M, Hescheler J, Schneider T (2018) Reciprocal modulation of Cav 2.3 voltagegated calcium channels by copper(II) ions and kainic acid. J Neurochem 147:310-322. https://doi.org/10.1111/jnc.14546

25. Niidome T, Kim M-S, Friedrich T, Mori Y (1992) Molecular cloning and characterization of a novel calcium channel from rabbit brain. FEBS Lett 308:7-13

26. Olcese R, Qin N, Schneider T, Neely A, Wei X, Stefani E, Birnbaumer L (1994) The amino terminus of a calcium channel $\beta$ subunit sets rates of channel inactivation independently of the subunit's effect on activation. Neuron 13:1433-1438

27. Pereverzev A, Leroy J, Krieger A, Malecot CO, Hescheler J, Pfitzer G, Klockner U, Schneider T (2002) Alternate splicing in the cytosolic II-III loop and the carboxy terminus of human E-type voltagegated $\mathrm{Ca}^{2+}$ channels: electrophysiological characterization of isoforms. Mol Cell Neurosci 21:352-365

28. Perez-Reyes E (1998) Molecular characterization of a novel family of low voltage-activated, T-type, calcium channels. J Bioenerg Biomembr 40:313-318

29. Perez-Reyes E, Schneider T (1994) Calcium channels: structure, function, and classification. Drug Dev Res 33:295-318 
30. Perez-Reyes E, Cribbs LL, Daud A, Lacerda AE, Barclay J, Williamson MP, Fox M, Rees M, Lee J-H (1998) Molecular characterization of a neuronal low voltage-activated T-type calcium channel. Nature 391:896-900

31. Randall AD, Tsien RW (1997) Contrasting biophysical and pharmacological properties of T-type and R-type calcium channels. Neuropharmacology 36:879-893

32. Raybaud A, Baspinar EE, Dionne F, Dodier Y, Sauve R, Parent L (2007) The role of distal S6 hydrophobic residues in the voltagedependent gating of CaV2.3 channels. J Biol Chem 282:27944 27952

33. Schneider T, Wei X, Olcese R, Costantin JL, Neely A, Palade P, Perez-Reyes E, Qin N, Zhou J, Crawford GD, Smith RG, Appel SH, Stefani E, Birnbaumer L (1994) Molecular analysis and functional expression of the human type E $\alpha 1$ subunit. Receptors \& Channels 2:255-270

34. Schramm M, Vajna R, Pereverzev A, Tottene A, Klöckner U, Pietrobon D, Hescheler J, Schneider T (1999) Isoforms of $\alpha 1 \mathrm{E}$ voltage-gated calcium channels in rat cerebellar granule cells - detection of major calcium channel $\alpha 1$-transcripts by reverse transcription-polymerase chain reaction. Neuroscience 92:565-575

35. Siapich SA, Wrubel H, Albanna W, Alnawaiseh M, Hescheler J, Weiergräber M, Lüke M, Schneider T (2010) Effect of $\mathrm{ZnCl} 2$ and chelation of zinc ions by N,N-diethyldithiocarbamate (DEDTC) on the ERG b-wave amplitude from the isolated and superfused vertebrate retina. Curr Eye Res 35:322-334

36. Simons C, Benkert J, Deuter N, Poetschke C, Pongs O, Schneider T, Duda J, Liss B (2019) NCS-1 deficiency affects mRNA levels of genes involved in regulation of ATP synthesis and mitochondrial stress in highly vulnerable substantia nigra dopaminergic neurons. Front Mol Neurosci 12:252. https://doi.org/10.3389/fnmol.2019. 00252
37. Soong TW, Stea A, Hodson CD, Dubel SJ, Vincent SR, Snutch TP (1993) Structure and functional expression of a member of the low voltage-activated calcium channel family. Science 260:1133-1136

38. Vajna R, Schramm M, Pereverzev A, Arnhold S, Grabsch H, Klöckner U, Perez-Reyes E, Hescheler J, Schneider T (1998) New isoform of the neuronal $\mathrm{Ca}^{2+}$ channel $\alpha 1 \mathrm{E}$ subunit in islets of Langerhans, and kidney. Distribution of voltage-gated $\mathrm{Ca}^{2+}$ channel $\alpha 1$ subunits in cell lines and tissues. Eur J Biochem 257:274-285

39. Wakamori M, Niidome T, Rufutama D, Furuichi T, Mikoshiba K, Fujita Y, Tanaka I, Katayama K, Yatani A, Schwartz A, Mori Y (1994) Distinctive functional properties of the neuronal BII (class E) calcium channel. Receptors \& Channels 2:303-314

40. Wall-Lacelle S, Hossain MI, Sauve R, Blunck R, Parent L (2011) Double mutant cycle analysis identified a critical leucine residue in the IIS4S5 linker for the activation of the $\mathrm{Ca}(\mathrm{V}) 2.3$ calcium channel. J Biol Chem 286:27197-27205

41. Williams ME, Marubio LM, Deal CR, Hans M, Brust PF, Philipson LH, Miller RJ, Johnson EC, Harpold MM, Ellis SB (1994) Structure and functional characterization of neuronal $\alpha_{1 \mathrm{E}}$ calcium channel subtypes. J Biol Chem 269:22347-22357

42. Zamponi GW, Striessnig J, Koschak A, Dolphin AC (2015) The physiology, pathology, and pharmacology of voltage-gated calcium channels and their future therapeutic potential. Pharmacol Rev 67: 821-870. https://doi.org/10.1124/pr.114.009654

43. Zhang J-F, Randall AD, Ellinor PT, Horne WA, Sather WA, Tanabe T, Schwarz TL, Tsien RW (1993) Distinctive pharmacology and kinetics of cloned neuronal $\mathrm{Ca}^{2+}$ channels and their possible counterparts in mammalian CNS neurons. Neuropharmacology 32: $1075-1088$

Publisher's note Springer Nature remains neutral with regard to jurisdictional claims in published maps and institutional affiliations. 